\title{
Circumscribing the Horizon in Jane Urquhart's The Underpainter
}

Anne-Sophie Letessier

\section{(2) OpenEdition \\ 1 Journals}

Electronic version

URL: https://journals.openedition.org/ces/8319

DOI: $10.4000 /$ ces.8319

ISSN: 2534-6695

Publisher

SEPC (Société d'études des pays du Commonwealth)

\section{Printed version}

Date of publication: 1 September 2010

Number of pages: 93-104

ISSN: 2270-0633

\section{Electronic reference}

Anne-Sophie Letessier, "Circumscribing the Horizon in Jane Urquhart's The Underpainter",

Commonwealth Essays and Studies [Online], 33.1 | 2010, Online since 11 December 2021, connection on 20 January 2022. URL: http://journals.openedition.org/ces/8319; DOI: https://doi.org/10.4000/ces. 8319

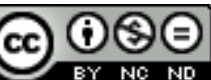

Commonwealth Essays and Studies is licensed under a Licence Creative Commons Attribution - Pas d'Utilisation Commerciale - Pas de Modification 4.0 International. 


\section{Circumscribing the Horizon in Jane Urquhart's The Underpainter}

This paper discusses the ongoing preoccupation of Canadian novelist Jane Urquhart with the influence of the visual arts on sensitivity, and, more specifically, the anxiety regarding the primacy of vision that permeates The Underpainter (1997). In this ekphrastic novel, Urquhart's treatment of the pictorial motif of the horizon engages the reader in a reflection on the very foundations of representation, in turn raising questions about the politics of the gaze underlying a painter's work.

7 anadian author Jane Urquhart has never ceased to reflect upon the endurance and seductive power of the cultural prisms that mediate the perception of space and its representations. It is thus unsurprising that The Underpainter, her fourth novel, should feature a painter "fascinated by the actuality of the north," and whose early work is quite reminiscent of the paintings of the Group of Seven (40). Urquhart, however, refuses to give her readers an elaborate description of the rugged landscapes of stark beauty they might be expecting. Her narrator only casually mentions the group of painters who became emblems of an emerging national consciousness in the 1920s on account of their vocal disrespect for the academic conventions of European painting, and their desire to render the uniqueness of the Canadian landscape. Urquhart's attention, however, slightly strays from the negotiation of cultural heritage, and its adjustment to a new geography. By creating a character who is a landscape painter, she probes into the foundational ambivalence of landscape. Etymologically, the term designated first the pictorial representation of a tract of land before it came to refer to its perception, namely "a portion of land that the eye can comprehend in a single view." (Webster's Dictionary) The aesthetic value attached to the word highlights that "our apprehension of space in a composition we identify as landscape conjoins what is seen with a way of seeing it." (Omhovère 2007, 56) The perception of landscape indeed requires the mediation of an educated eye responding to latent aesthetic and cultural models, a process which Alain Roger calls the artialisation in visu (Roger 17).

The Underpainter is informed by an implicit identity between narrating I and perceiving eye (Urquhart 1997, 179). The novel's narrator, Austin Fraser, accordingly fulfils the part of the paradigmatic "personnage porte-regard" (literally the "gaze-bearer") ${ }^{1}$ so crucial to the descriptive economy of the realistic novel. At

1 Philippe Hamon coined this expression to refer to the perceptual focalizer which is produced by description and traditionally naturalizes its insertion in the realist novel (172). 
plot level, the painter is defined by his extraordinary "visual memory, [his] eidetic malediction" (55) through which he reminisces the events that marked his quest towards originality. In the course of the story, he turns these events into paintings, the descriptions of which punctuate the text. Formally, the series of analepses, or resurfacing memories, create a multi-layered narration which mirrors "the line, form and composition" of the underpainting faintly visible through the superimposed layers of paint (181).

The Underpainter occupies a special place in Urquhart's reflection on the influence of the visual arts on sensitivity. More than any of her works of fiction, this ekphrastic novel explores a certain anxiety regarding the power and prevalence of sight in Western culture. Coinciding with the line at which the sky and earth appear to meet, the horizon exemplifies the issues that the primacy of vision raises. As a limit from which the invisible beyond "begins its presencing" (Heidegger 154), the horizon suggests that representation is always local, bounded in space and in time. As such, the horizon partakes of an interrogation on the very foundations of representation. But the horizon is also a line that defines the scope of the gaze. Determined by the viewpoint of an observer separated from the scenery s/he contemplates, the horizon supposes a politics of the gaze. In the novel, Austin Fraser has no desire to puncture the horizon and see beyond its limitations. On the contrary, his early visual experiments try to circumscribe and to possess it. Of course, they are doomed to fail, and eventually lead to an artistic crisis. Austin only becomes an original artist when his painting undermines the truism according to which a painter not only paints with the eyes, but also paints for the eyes. The title of his most famous achievement The Erasures draws attention to what the painting withholds from vision, and thus bespeaks a pictorial project which can be read as a paradoxical attempt to "mute or tamper with the aura of the image." (Omhovère 2010, 13)

Looking back on his early career, Austin concludes that "what [he] wanted from life was just a good view [...] a perfectly composed view, and, now and then, a perfect figure in a perfect landscape," (141) like the two canvases he made of "Sara standing by windows, looking out towards the frantic lake, the hectic sky." (167) The motif of the window, although unobtrusive in the novel, is central in Austin's art. During the fifteen summers he spends in Silver Islet, he ceaselessly paints the views of "the lake, the landscape and the sky" from Sara's cabin (318). The ideal of harmonious composition he strives to reach is closely linked to the notion of prospect, this "ordered vision from afar" (Omhovère 2007, 68) created by perspective, and enhanced in the composition of pictorial space by the motif of the window. Its frame has indeed a twofold function: it transforms space into a tableau, creating thus an effect of mise en abyme, and it also contributes to the creation of the pictorial illusion, namely the illusion of depth and threedimensionality. ${ }^{2}$

2 The image of the painting as window is central in Leon Battista's definition of linear perspective: the picture plane is thought of as a transparent window through which the viewer can see the pictorial world. (Omhovère 2007, 23-24) 
Despite his love for "long views and [...] aerial perspective," (130) Austin enigmatically declares that he "painted the horizon in a crisp possessive way, as if, having chosen to render it, [he] felt [he] must bring it up close for inspection." (130) This statement sharpens the meaning of a previous reference to the horizon: "I never painted the horizon, wanted only to capture the effect of it." (100) Beyond the contradiction - Austin is not an entirely reliable narrator - both passages are to be interpreted, on the most obvious level, in terms of experiments with pictorial composition. The position of the line of horizon being determined by the construction of pictorial space, its "effect" can be construed as meaning both the dynamic interaction between the object and the space around it, and certain effects of light and texture. These pictorial experiments also evince a desire for mastery, a will to control experience through rational understanding. Austin regards his sketches and studies as "theoretical exercises in intimacy." (101) The unexpected association of words draws the reader's attention to the shift of meaning at work in the artist's use of the word "intimacy." The intimacy he explores is both a summation and a totalisation since it cannot be dissociated from the "crazy inventory" he makes of his lover's house (164). Year after year, Austin paints the same views, the same woman, the same objects until his memory is saturated with images which, forty years later, he can conjure up to create a new episode in his narrative (15). His paintings do not merely try to circumscribe Sara's world. In his studies, Austin endlessly records possible visual impressions that constitute the multiple facets of his subject of which he has only a limited perception at a time. ${ }^{3}$ In this respect, it is unsurprising that he should become interested in cubism later on in his career. Even though cubism departs from pictorial illusionism, it still plays, to a certain extent, with the viewer's perception of two and three-dimensional space. With the multiplication of viewpoints, the object is depicted on the picture plane as if all its facets were visible at the same time. As a result, the painter's "stylized mountain[s]" (268) further his early visual experiments with methods of representing forms in space.

What underpins Austin's exploration of the structure of perception (Pitavy 158) is an "intellectualisation of vision." (Matos Dias 101) Indeed, for the painter, sight is an intellectual sense concerned with identification and objectification, both of which he believes he can manipulate. A "master of selectivity," he revels in the fact that he "[is] able to discard frivolous stimuli at will." (82) He adopts a strategy of containment: "That which [is] not in [his] line of vision at any one point $\mathrm{d}$ [oes] not interest [him] for the simple reason that [he is] not looking at it." (130) His refusal to acknowledge what exceeds his necessarily limited perception partakes of an illusion that the world can be held whole by the viewer - if he chooses to

3 The object contains more than is ever given at one time and from one point of view. It presents only one facet to the viewer, the others being "appresented" on the horizon of the visual field. All these facets constitute what Husserl calls "the internal horizon" or "horizon of the object." (Collot 16) 
- because of its transparency and univocality. In a sense, Frazer misinterprets the coincidence between the "eye" and the "I" so dear to his mentor Robert Henri. Vision ceases to be a response to the world, and becomes detached from it, a projection of the mind, which encourages narcissistic withdrawal. The narrator states dispassionately: "In the end, we painted ourselves over and over." (178)

On the picture plane, this intellectualisation of vision is related to a rationalisation of sight. Whether it be in his figurative pieces or in his abstract canvas, the painter's (intellectual) space is mathematical, as pictorial composition determined by perspective orders his various and random visual sensations. Significantly, when explaining his art, Austin uses the architectural metaphor of the fortified village, an image that emphasizes once again he idea of containment since the painter insists on "the village, the walls and gates - the structure, the method." (180) He advocates the primacy of disegno - drawing and design, that is, the artist's conceptualization - over colour: "One may venture out into the valley, out into colour and texture, but the truth is, the fortified village is where one really lives." (180) What the painter fears, what the "invading armies" stand for, the text does not say. But an earlier episode sheds light on the opposition between colour and design. The narrator explains how he would experiment with "visual intimacy [by] moving the object closer and closer until proximity obliterated meaning as [he] always suspected it would." (54) We find in this passage the same intriguing use of the notion of "intimacy" relating to visual experiments. The visual effect created by extreme close-up belies identification, the object losing shape to become a blur of colour. Colour perception alone thus precludes objectification, which is the first step in an intellectualisation process. Whenever the narrator recalls his portraits of Sara, the description focuses on postures, lines and shapes rather than on colour. The painter's eye dissects the structure of his subject, and reduces his lover to "a series of forms on a flat surface, her body a composition adapting to a rectangle." (96) It is quite literally her anatomy, the structural makeup of her body that fascinates him the first time he meets her: "a strong slim back, her shoulder blade shifting as she moved the broom," (14) a gesture the young Austin immediately tries to capture in a sketch. Dehumanized as she is, Sara seems to disappear behind an excess of visibility. The episode relating Austin and his friend and mentor Rockwell Kent's ${ }^{4}$ falling out (253-262) underscores that the young artist's paintings remain lifeless because his creative process denies his lover's flesh; despite his technical proficiency, only "coldness" (261) and "emptiness" (307) emanate from Sara’s portraits.

\footnotetext{
4 American painters Robert Henri (1865-1929), Abbott Thayer (1849-1921) and Rockwell Kent (1882-1971) are historical but fictionalised characters, as Jane Urquhart points out in her Acknowledgements. Robert Henri is certainly the most well-known, since he was the leading figure of the realist artistic movement called the Ashcan School and a prominent member of the group known as The Eight (Castria Marchetti 144-148).
} 
Obsessed with distance, driven by the thrill of just looking at "flagrant acts of exposure," (69) the young Austin is both a tourist and a voyeur, two traits that are, the narrator confesses, "a vital part of [his] personality." $(69-70)^{5} \mathrm{He}$ is no different from the American "tourists who wan $[\mathrm{t}]$ the view from Lake Superior's north shore" (13) or who stare from their cars at the huge peninsula of rock called Sleeping Giant (2). Significantly, after the falling out with Rockwell Kent over his paintings of Sara, he is overwhelmed by the impression that the landscape of Silver Islet "look[s] used and cheap." (264) Consuming sightseeing as a form of recreation, tourists collect views - snapshots, postcards - which are infinitely reproducible, since they are taken from prescribed viewpoints. As a matter of fact, the painter himself has capitalized on this fascination for "the glamour of the north," (45) and transformed its visual enjoyment into a commodity: "Wealthy New Yorkers, it turned out, loved wilderness landscapes. They wanted rocks and water, twisted trees and muskeg on their smooth plastered walls." (96) For the modern reader, the passage tends to read as a pictorial template. Minimal as it is, the description features all the staples of the Group of Seven, and Lawren Harris's paintings of stark lakesides immediately come to mind. ${ }^{6}$ Less obvious is the contrast between the allusion to the rugged beauty of the landscape and the reference to the materiality of the walls, which highlights that, just like the tourists in their cars, Austin's patrons want to enjoy a carefully managed view, one that is already framed and therefore safely contained.

The pictorial template also underscores that the images of the wilderness and the north - the two cannot be dissociated - are indeed tropes. They at once derive from, and mediate the perception of landscape, the viewer looking for familiar configurations that will allow him/her to construct landscape out of indiscriminate space. By extension, those terms are descriptive (to a certain point) but, more importantly, they embody political, economic, imaginative assumptions and expectations that are evidenced in the descriptions of the Sleeping Giant. Terms like "obdurate, unyielding," "unconscious," (2) "rigid and unchanging" (333) emphasize the permanence of the overwhelming natural phenomenon, and reinforce the European convention that identifies nature as "a separate space" (New 28) to be kept under human control. Like the Canadian Shield in earlier texts, the Sleeping Giant comes to symbolize "Canada's 'limitless' size and 'untapped' resources, its indeterminate dimensions and echoing solitude." (New 170)

During the only summer he spends in Silver Islet, Austin's father asks the young art student to draw a view of the silver mine in which he has invested. The scene alludes to, and plays on the double meaning of the eighteenth-century landscape

5 Austin begins the story of his life by pointing out that Rochester, his birth-town, is famous as the home of the Kodak Brownie camera (17). Because the camera allows the viewer to distance him/herself from the scene by looking through a lens, it is the object par excellence of both the tourist and the voyeur.

6 See, in particular, Maligne Lake, Jasper Park (1924). 
word "prospect" which refers to both an extensive view and "a place showing signs of containing a mineral deposit." (Webster's Dictionary) What is more, in the Ojibway legend, the creation of the Sleeping Giant is the result of the colonial plundering of natural resources (172). Ironically, it is only when he acknowledges his own disinterest in the supernatural history of the site that the narrator can confess: "My father and I both exploited the landscape - differently, it's true - but we had exploited it nevertheless." (327) The parallel between the artist and the prospector entices the reader to reconsider Robert Henri's unexpected analogy between art and mining. He repeatedly uses the conventional image of depth in his disquisitions on the artist's relation to the world. Austin's mentor indeed promotes a de-cryptive art that strives to reveal what remains hidden, the artist painting because he sees what others cannot see. He enjoins his students to look beyond the surface of ordinary life into "the deeper current" of existence (83). Austin, however, is obsessed with the surface of things, the how of appearing. In the narrator's interpretation of the image, there is a shift in the relational identity that links the two units: the point of comparison becomes the ruthless exploitation "at the expense of nature and humanity," "the greed." (84) The violence conveyed by the words used to describe Austin's father's activities - his investments " $t$ [earing] open the wilderness, penetrat[ing] the earth" (84) - can be explained by the fact that WWI serves as the historical backdrop of the novel. ${ }^{7}$ But the violence of the war also finds a disquieting echo in the images the narrator chooses when he explains his own creative process: "Jealously hoarding my own experiences, the intimacy I courted became an invasion, almost a form of rape." (180, see also 107, 33) He is a "visual bandit" (156) who mines Sara's memories of her father and her stories about their landscape, just as he mined Augusta's childhood anecdotes. His exploring the narratives of both women is akin to an act of despoilment insofar as, through the act of creation and re-presentation, they are "unhinged from their original site of meaning," (Gordon 64) the painter re-constructing them to serve his own conceptualization and intention. With Augusta, however, he can no longer pretend that "the act of making art filled the space around [him] so completely there would be no other impressions possible beyond the impressions [he] controlled," (170) hence his disappointment in Night in the China Hall, a painting related to what the young woman told him. As the narrator explains, "Augusta's character - what [he] was to know of it - would not permit obviation." (151) Using only what he thinks will improve his paintings, he resents his model's actuality, because he considers that it interferes with his creative process. Nowhere is this more striking than in his reaction to Sara's surprise visit to New York: "She belonged in a light-filled room in the north, a room with a view of landscapes I

\footnotetext{
7 See Marta Dvorak's recently published discussion of how Austin's canvasses are not only deliberate de-constructions characteristic of the epistemological crisis coterminous with modernism, but also on how they become "political metonyms of the collateral damage of war - the destruction of western culture and the alleged impossibility (after the Great War) of meaningful representation ever arising again" (93).
} 
could frame and sell, her body frozen into poses I could also frame and sell." (98) Her visit is "unacceptable," intolerable because by stepping out of the frame the painter has imposed on her, she ceases to be an object offered to the gaze that he can endlessly manipulate on the picture plane.

The nude in a landscape is a construct marked by gendered and power associations reminiscent of the patriarchal discourse that feminizes the land and constructs it as the territorial prerogative of the hero / explorer / adventurer (New 110). The "fortuitous combination of landscape, class and gender" (143) that first attracted the painter's interest draws upon an established system of authority that confirms his position of power. It would not be far-fetched to say that this is the very reason for his early success. His paintings represent what is seen by someone who sees Sara, "a miner's daughter in a northern setting" (143) as the marginal, a position with which his wealthy patrons can identify because it reinforces their own ideological framework. Urquhart, however, reverses the topos of the feminized landscape. As his death approaches, the painter painfully recollects his emotional failures in a narrative which eventually leads him to identify, paradoxically, with the landscape his younger self exploited: " "I will paint myself with the love I could not accept coming towards me, despite my cloak of fear, the implacable rock man, the miles and miles of ice." (340, my emphasis)

The text constantly oscillates between pathos and bathos as the narrator repeatedly mocks the presumptuousness of his younger self in order to stave off despair. The young Austin appears as a "pontificator" (83) adopting poses he thinks are "suitable for a person of artistic temperament," (45) mimicking his teachers, and lecturing others about "real art." $(51,73)$ As an old man, he wonders if his "creative activity at the time was nothing more than a recital by rote of appropriate learned response" (252, my emphasis), a phrase which underlines the problematic prescriptive nature of cultural and aesthetic models. Taught to value sublime sceneries by his mother, the narrator explains, in a tongue-in-cheek comment, that it is "no surprise to [him] given the abysses in the surrounding geography, that men famous for mail chutes and elevators should have flourished in [his] native city." (23) The same burlesque scaling-down with its insistence on the mundane operates in his mother's description of the landscape that fascinates her, as when she exclaims, staring from a bridge: "Down you'd go, just like a love letter in a Cutler chute." (23) The obvious gap between the codes of the sublime experience - the edge of the precipice ${ }^{9}-$ and the practical concerns of

8 When I interviewed her in May 2008 at the SAES conference held in Orléans at which she was the key speaker, Jane Urquhart explained: "In a book about someone who is unconscious of his own actions, someone who is ignoring the effects those actions have on others, perhaps someone who is dreaming, a landscape feature such as that becomes a gift, particularly because I chose to set the novel on that peninsula for a narrative, rather than a symbolic reason."

9 With Romanticism, and its search for "delightful horrors," caves come to be associated with the sublime experience: "To be profound was to plumb the depths. So it would be 
everyday life - the mailing of a letter - is a locus of creation for Austin's mother. The unlikely combination of images allows her to devise a language that expresses her own sense of place. Her son, however, "search[es], unsuccessfully, for signs of chasms and falling water" in summer pastures overlooking the lake (52). The irony underlying the passage draws the reader's attention to the tensions between what is seen and ways of seeing it. The aesthetic patterns Austin tries to identify and the aesthetic response to space he tries to emulate impinge on his perception and eventually screen actual space which "reced[es] infinitely through the successive framing." (Omhovère and Lanone 9) The motif "Ontario Lake Scenery" may be taken as a paradigmatic account of this cultural mise en abyme. Upon seeing it for the first time, on the last piece of George's broken china collection, Austin notes the obvious discordance between the representation and its setting, the elegant ladies, ruined castles, and East Indian tents, and the actual Great Lake Ontario. This leads him to ponder on his own art:

But how much different is this from the complicated preconceptions I have carried with me? Had the potter visited Ontario, would he have been able to see past the fog of his fantasy straight through the reality of swamp and muskeg, blackflies and bad weather?

$[\ldots]$

Or would the elegant ladies, the romantic ruin, the non-existent mountains have persisted, blocking his view, keeping him distant from his own life? (336)

For the Staffordshire potter who had never been to Upper Canada except in his imagination, the "theatrical mirage" (336) with the juxtaposition of European looking ruins and aboriginal tepees is another cliché functioning as a substitute in the representation of what the eye cannot see (Pitavy 165). In the novel, china painting is presented as an alternative to the canon of high art, embodied by Robert Henri, Rockwell Kent and Austin himself. With its disregard for the laws of composition, it departs from pictorial illusionism, and the narrator repeatedly underlines how laughable he found its "improbable bridges" (77) and its "improbable, cerulean landscape." (123) Urquhart, however, seems fascinated by the way china painting suggests rather than represents landscapes, notably through highly stylized and sometimes codified elements and the non-figurative use of the colour white.

Although Austin, somewhat belatedly, admits his part in George's and Augusta's suicide,$^{10}$ the comforting paradigm of the Künstlerroman his narration

in shadow and darkness [...], in caves and chasms, at the edge of the precipice [...], in the fissures of the earth, that [Edmund Burke] insisted in his Inquiry, the sublime would be discovered." (Schama 450)

10 Austin decides on a whim to reunite George with his long-lost love. His playing at directing other people's lives will lead to his friend's suicide. Recalling the tragic denouement, the narrator draws a parallel between the scene his younger self involuntarily staged and the composition of a painting: "George believed that I had never understood, that I was 
follows suggests that the tragedy, as well as the betrayal of Sara, was necessary to the accomplishment of what was latent in him: the emergence of the original painter. The two events are indeed presented as the catalyst that provokes Austin's dramatic stylistic change. In an effort to detach himself from the "perfectly composed view[s]" (141) and from the deadly consequences of the will to control they express (215), the painter develops the concept of "formal ambiguity" created by the application of several layers of paint over an original canvas.

The American painter Abbott Thayer, who published a treaty on protective colouration in nature, first introduces Austin to the idea of concealment (243250). With his obsession with the War Department, his acute paranoia, and his fascination with angels and winged beings, the character is rather ridiculous, but his idea of disguise leaves its imprint on Austin's mind. If his series The Erasures represents "the entirety of [his] life," the narrative he wanted to offer Sara (331) but could only share with his art, it could be argued that the superimposed layers of paint erasing the underlying image is another way for the painter to distance himself from his subject, while satisfying his obsession with control. After all, the novel alludes to the influence of Thayer's treaty on the use of military camouflage during WWI. The text, however, warns the reader against misinterpretations, and the risk of dissociating the underpainting from the overpainting, the act of erasure from the carefully rendered image. Austin adds in a tongue-in-cheek comment, "there is nothing [...] like an obscured subject to give the critics something to talk about." (183) He insists on his art as a form of "exorcising" (216) of the past, and presents his paintings as receptacles of "grief" and remorse, "rectangle[s] of sorrow." (184) The spectres that continue to haunt the painter, what he calls his "eidetic malediction," (55) would thus be represented on the canvas by "pentimenti: those ghosts of formerly rendered shapes that the artist had intended to paint out forever." (181) The recurring references to painting as a cathartic act make the interpretation of the paintings seemingly obvious, all the more as the word pentimenti derives from the Italian pentirsi, meaning "to repent." Furthermore, the technique itself seems very much linked to the denouement of the tragedy Austin provoked. The whiteness of the overpainting is indeed quite reminiscent of the view of the snow-covered ice on Lake Superior that the painter discovers from his window in the hotel of Port Arthur. Having called Sara in the hope of finding a form of atonement in her presence, he waits for her to come into view in the winter landscape, "a black dot on that vast white sheet" (330) sometimes vanishing into white. But unable to come to terms with his own desire for "exposure" (331), he leaves without even talking to her. This scene evokes the image of a receding figure on a horizon which is also characteristic of The Erasures, and can also be related to the narrator's intense sense of guilt.

responsible, that the scene that greeted me in this boyhood room had been created by me as surely as if it were a painting I had completed with my own hand." (312) 
Yet The Erasures series insistently seems to mean more. What is at stake in this series is a defamiliarisation of the object. Austin's pictorial technique strays from the optical illusion of depth created by pictorial composition, and works on the materiality of the hard surface, the superimposed layers of paint. The pentimenti have thus a twofold effect: by altering perception, that is, the way the object is visualised in painting, the painter leads the viewer to the edge of visibility, and entices his/her gaze to become interrogation. In a sense, Austin explores with this technique the intuition that marked the beginning of his artistic crisis:

The problem as I began to see it towards the end of my attachment to realism was that I had lost sight of the necessary interval on the picture plane, the visual pause that had happened quite naturally when I still worked with landscape, still worked with the spatial interrelation of rendered form. There was always a break in details of rocks, say, or foliage, an unencumbered space that pushed forward from distance, something large and immeasurable, like sky or water. (221)

The impression of openness the narrator alludes to is produced by pictorial composition, namely the representation of a horizon. But the horizon is both a principle of opening and a sign of the limits of seeing. Indeed, it opens a perspective toward the infinite of the world itself whose presence always exceeds perception as its vanishing point ceaselessly recedes beyond the gaze (Collot 24). When trying to explain his stylistic change, Austin comes to the conclusion that The Erasures are "'about' both revelation and obscuration," (181) a sentence which calls to mind the phenomenological analysis of the indivisible link between donation and withdrawal which shapes all manifestations of the world. As Michel Collot explains, the object can only reveal itself by hiding one of its facets, and thus retains an invisible, enigmatic dimension. Just as it offers itself to the beholder, there is something in it that eludes the senses and signification (Collot 16-18). Perspective exemplifies this relationship between obscuration and withdrawal because it is defined by a gaze which is incarnate and therefore limited in space and time (Collot 23).

The same presence / absence paradox structures the perception of time and The Erasures, which, because of their emphasis on resurgence, explore the horizon of the past. ${ }^{11}$ At first, Austin seems to revel in his "overdeveloped powers of recollection," (107) a leitmotiv in the novel. Soon enough his egotism gives way to an acute sense of dereliction. The narrator can only exclaim: "how crowded and how unfocused this looking back is." (217) The explicit reference to photography is significant since photography suspends time, and creates "fixed images." (17) Because of its illusory transparency, it seems to preserve images of the past as pure antecedents. On the contrary, the phenomenon of retention that underlies remembrance entails their constant modification, which is both the source and

11 The concluding section of the article is based on Michel Collot's seminal essay La poésie moderne et la structure d'horizon, and more precisely the chapter entitled "Extases du temps, temps de l'extase." 
the consequence of the indeterminability that haunts the painter: "Slicing into the lives of others, I have walked away with only disparate pieces; walked away with both permanent and fugitive colours, distinguishable and vague shapes." (107) Retrospection cannot give a fixed and comprehensive view of the past, all the more as the narrator cannot distinguish between his own images and those he took from others. He ceaselessly paints this "uncertainty" that is his "true inheritance." (217) On the picture plane, the multiplicity of unexplored associations onto which remembrance opens is represented by the "premonition of pentimenti" (181) which are all "potentially capable of affecting the surface above," and, therefore, of altering the painting when they rise to the surface through the layers of white pigments.

Whether it be the inexhaustible depth of the past onto which retrospection opens, or the inexhaustible depth of landscape of which the line of horizon is a manifestation, the emphasis is laid on what is hidden, and therefore belies determination and objectification. The Erasures mark a dramatic rupture with Austin's earlier visual experiments insofar as it testifies to an interest in the enigma of the visible which becomes for the painter a creative space. The pentimenti could thus be construed as an attempt to represent the invisible inscribed in the very texture of the visible.

As a Künstlerroman, The Underpainter dramatizes the education of a landscape painter's gaze. Interestingly, Alain Roger relates the invention of the window to the emergence of the Western notion of landscape. Artialisation in visu requires the distance created by the window for culture to endow space with an aesthetic appeal, a process which Roger sums up in his portmanteau word "recul-ture" yoking together the French words recul (or distance) and culture (Roger 17). In Urquhart's novel, however, Austin, who effectively distances himself from his subject, regards it as the mere means of serving economic and aesthetic needs. The framing of landscape, the artialisation process this implies are indeed fraught with power relations which the novel ceaselessly probes. It is only when his "eidetic cinema" (80) fails him that Austin can appease his ghosts. This moment of "clouded vision" (Urquhart 1990, 173) finally allows him to go beyond the window glass and to answer the call that emanates from the horizon:

Tonight I will begin The Underpainter, the last canvas of the series, a portrait of myself. [...] It will be full of beautiful dark shorelines, this painting, full of all the possibilities we believe exist in alternative landscapes, alternative homelands. Hills and trees, gold-leaf birches, skies and lakes and distances. (339-340)

Anne-Sophie LETESSIER Université Paul-Valéry Montpellier 3 


\section{Works Cited}

Castria Marchetti, Francesca, and Ida Giordano. La Peinture américaine. Paris: Gallimard, 2002.

Collot, Michel. La poésie moderne et la structure d'horizon. 1989. Paris: PUF, 2005.

Dvorak, Marta. "When the Underpainting Shows Through : Jane Urquhart's Resurgent Transmutations." Resurgence in Jane Urquhart's Oeuvre. Ed. Héliane Daziron-Ventura and Marta Dvorak. Bruxelles, New York : Peter Lang, 2010. 91-107.

Gordon, Neta. "The Artist and the Witness: Jane Urquhart's The Underpainter and The Stone Carvers." Studies in Canadian Literature/Etudes en Littérature Canadienne 28.2 (2003): 59-73

Hamon, Philipe. Du descriptif. Paris: Hachette, 1997.

Harris, Lawren. Maligne Lake, Jasper Park. 1924. Oil on canvas. 122.8 x $152.8 \mathrm{~cm}$. National Gallery of Canada, Ottawa.

Heidegger, Martin. "Building, Dwelling, Thinking." Poetry, Language, Thought. Trans. Albert Hofstader. New York: Harper and Row, 1971. 143-62.

Lanone, Catherine, and Claire Omhovère. "Mourning / Mocking Browning: The Resurgence of a Romantic Aesthetics in Jane Urquhart's The Whirlpool." Commonwealth Essays and Studies 31.1 (2008): 8-21

Letessier, Anne-Sophie. Personal Interview with Jane Urquhart. Orléans, 16 May 2008.

Matos Dias, Isabel. Merleau-Ponty: Une poïétique du sensible. Trans. Renaud Barbaras. Toulouse: PUM, 2001.

New, W. H. Land Sliding: Imagining Space, Presence, and Power in Canadian Writing. Toronto: U of Toronto P, 1997.

Omhovère, Claire. Sensing Space: The Poetics of Geography in Contemporary EnglishCanadian Writing. Brussels: Peter Lang, 2007.

_. "The Artialisation of Landscape in Jane Urquhart's The Whirlpool." Crosstalk: Canadian and Global Imaginaries in Dialogue. Ed. Diana Brydon and Marta Dvorak. Waterloo: Wilfrid Laurier UP, forthcoming.

Pitavy, Danièle. “Territoires en miroir: écriture et peinture chez Jane Urquhart." Etudes Canadiennes/Canadian Studies 47 (1999): 155-166.

Roger, Alain. Court traité du paysage. Paris: Gallimard, 1997.

Schama, Simon. Landscape and Memory. London: HarperCollins, 1995.

Urquhart, Jane. The Whirlpool. 1986. Boston: David R. Godine, 1990.

_. Changing Heaven. 1990. Boston: David R. Godine,1993.

_. The Underpainter. Toronto: McClelland and Stewart, 1997. 